\title{
Analysis on the Construction of Soft Power of Local Colleges and Universities in Shaanxi Province
}

\author{
Jiaojiao Mo \\ Xi'an Peihua University, Xi’an, Shaanxi, 710125
}

Keywords: SPC, control charts, process capability

\begin{abstract}
This paper studies the construction of soft power in local colleges and universities in Shaanxi. The paper takes Shaanxi local colleges and universities as the research object, focuses on the status quo, problems and causes of soft power in local colleges and universities in Shaanxi, and comprehensively analyzes the corresponding countermeasures. On the basis of a brief introduction to the research background, significance and status quo, the paper puts forward two main directions to seek breakthroughs to clarify the soft power of colleges and universities, "soft power", "hard power", "cultural soft power" and other related concepts. The intrinsic logical relationship between the localization and the foreignization of the soft power construction of local colleges and universities in Shaanxi takes Shaanxi local colleges and universities as a research unit to explore the effective path of soft power construction in Shaanxi local colleges and universities.
\end{abstract}

\section{Introduction}

The construction of soft power in colleges and universities and national and regional development. Colleges and universities are an important source of national soft power, an important platform for enhancing national soft power, and a frontier for national soft power competition. As the famous scholar Ding Xueliang commented, "The rise and fall of the university is closely related to the rise and fall of the great power. From the eleventh century to the present, where there is a rise of a top-ranking university, there is a rise of a country and the prosperity of a nation." Under the background of the fierce contemporary society, the university's talent cultivation and cultural-led functions make the university a sensitive and frontier position for cultural competition and penetration of different nationalities and countries. First-class countries need first-class cities with first-class higher education, first-class universities and first-class enterprises, and first-class talents. Colleges and universities are the talent pool and intelligence pump for regional economic development, which can provide them with continuous human and intellectual resources. The soft power of colleges and universities and the soft power of the region, especially the soft power of the city, are also a kind of interaction and mutual assistance. The radiation and attraction of university culture can enhance the visibility of the city and region where the university is located, expand its influence, and in turn promote the university's reputation and reputation, and also provide a good development environment and space for university development.

\section{College Soft Power and its Components}

With regard to the definition of university soft power, there is a similarly similar saying in the academic circles. Professor Li Huashu puts forward that "the university's soft power is the overall spiritual outlook of the university, the value and internal quality of the university, and it is an important component of the comprehensive strength and core competitiveness of the university. Part. ', 4 Professor Yu Guang proposed that "soft power refers to the overall spiritual style and internal quality of the university. It is a special school culture, including the university's spiritual character, school philosophy, development orientation, educational investment, human resources, Disciplinary professional setting, management and operation mechanism belong to the university's "hidden resources". 1 Professor Cai Xianjin pointed out that "soft power is a kind of spiritual strength in the university, including school philosophy, development strategy, various institutions and personnel. 
The distribution of power and the planning and management of daily work, as well as the school spirit, teaching style, style of study, the morale of the school and the staff and teachers of the school, the state of the school, the culture of the university, the image of the university, the reputation and brand, etc. Etc., ultimately reflected in the university's influence on society and its attractiveness to students. "2 Professor Li Peigen believes that university soft power is a collection of factors that can express school energy but no clear indicators and data. Its constituent factors include inner spirit, internal management, external soft resources, and leadership literacy. 3 Analysis of the above academic circles With regard to the definition of soft power in colleges and universities, we can draw the following two basic understandings. First, the definitions basically replace the "higher universities" with "universities" to define soft power. Obviously, such definitions are generally based on their own Groups, levels and their characteristics are defined as foundations. There are certain limitations. Secondly, almost all definitions are defined by a static college soft power "including what". Most of the definitions are not inherent in the construction of soft power in colleges and universities. The basic rules of the operating mechanism are defined and tried, so it is not scientific and comprehensive.

\section{The Constituent Elements of College Soft Power}

Because the connotation of soft power at different organizational levels is different, the source of soft power is different. For a country, "soft power" comes from its cultural influence, ideological influence, institutional influence, and influence in foreign affairs. For different regions or universities in the same country, the source of soft power is clearly different. In other words, if a university does not pay attention to improving the quality of personnel training, but pays attention to ideology and foreign affairs, it is difficult to enhance its influence and it is difficult to enhance its soft power. As for the constituent elements of the soft power of colleges and universities, the academic circles have similar opinions. President Li Peigen believes that there are many factors in soft power, which can be roughly divided into four categories, namely, internal spirit, internal management, external soft resources, and leadership literacy. He further argued that "the inner spirit of the university is the most important factor in the soft power of the university. A good university must have its own fixed or even unique spiritual character. This includes mission, values, culture, culture, etc." "Internal management is an important embodiment of the university's soft power. Management should be the softest power that is most easily transformed into hard power. There are many internal management elements that reflect the university's soft power. The most important are strategic management, brand management, personnel management, and collaboration. Management, etc., "External resources mainly include government, industry, alumni, peers, etc." 1 Professor Li Huashu said that "the university's soft power is deeply embedded in the vitality, creativity and appeal of the university. In the discussion, it fully demonstrates the cultural, political, spiritual, institutional and other components of the university. $2 \mathrm{Fu}$ Xiaodong believes that the soft power of colleges and universities is the university spirit, university tradition, university philosophy, university system The comprehensive expression of many factors, such as the school wind, is the core values and intrinsic quality of a school's special crops, and Unique culture is determined. It includes the university's cultural power, the university's spiritual strength, the university's institutional power, the university's influence, and the university's affinity. Guo De, Ye Fei, and Hao Yue in January argued that the university's soft power index system specifically includes college culture, university spirit, university innovation, and university management. Luo Junfei and Peng Yuehua divided the structure of university soft power into five parts: "Spiritual Power, University Cultural Power, University Institutional Power, University Organizational Power, and University Public Relations”.

\section{Countermeasures for the Construction of Soft Power in Colleges and Universities in Shaanxi}

Thought is the most important and most important element in the soft power of colleges and 
universities. It is not only the "command" of all soft powers in colleges and universities, but also the "central force" that plays a guiding role in all educational activities and construction behaviors of colleges and universities. It is an organizational philosophy of colleges and universities. A profound reflection of the level of thinking. A person's thoughts determine his personality, and he decides that his future has no ideological guidance. Our life cannot find directions. There is no guide to correct thinking. The work we have worked so hard may be a mistake. The university's thinking reflects its degree and level of spiritual accumulation, determines its quality, and embodies its level of wisdom in thinking, grasping, planning its own reality and future future. The ideological power of colleges and universities is realized by the spirit of science, rational thinking, humanistic feelings, high-level pursuit and solid work. Local colleges and universities in Shaanxi should comprehensively improve their own ideological level by condensing the university's spiritual strength, maintaining the moral character of education, improving the decision-making power of education, and enhancing the educational transformation.

The cultural power of colleges and universities is the soft power that emerges from the excellent culture of colleges and universities. This cultural power is rooted in the essence of Chinese traditional culture. It is externalized into a variety of rational realities, noble spiritual consciousness, and good customs. It not only makes the university people feel glorious, confident, calm, and stunned. The university should maintain its density, hardness, resilience and color in the face of external cultural alienation. It is in a favorable position to actively restrict, radiate, influence and transform in the face of social secular culture. Colleges and universities are the halls of knowledge, and universities should also be the source of culture. The richness of knowledge does not necessarily indicate the richness of culture. If colleges and universities are rich in knowledge and materiality, they will not make their own culture reflect the vitality, influence and attraction of advanced culture. Instead, they will make foreign cultures and shallow pop cultures "professional and arrogant" on university campuses. Colleges and universities can only be counted as knowledge-based trading organizations and de facto cultural deserts. Excellent universities should have a cultural sensitivity, a cultural mission, a sense of cultural crisis, and build an excellent culture on this basis. For local universities in Shaanxi with weak cultural strength, we should not only have the concept of "campus culture" in the general sense, but also should consider the concept of "cultural campus" from the perspective of cultural power construction. All the education, teaching, academic research, daily management, and service activities of the school should be subject to high standards, so that the quality of each activity can be improved by pursuing excellence in teaching, research, management, and service. In turn, it gradually has the characteristics of cultural attributes, so that ordinary university activities are "culturalized", and then cultivate their own campus culture, characteristic culture, institutional culture, academic culture, behavioral culture, and finally form a good soft environment strength of local universities in Shaanxi.

The management ability of colleges and universities is the soft power of colleges and universities to promote the coordinated operation of the university through effective management service activities, so as to achieve maximum management benefits and optimize efficiency. The most important management power of colleges and universities comes from the macro thinking, system decision-making and corresponding strategic management of school decision-making. Although this has been discussed in the previous article, it is emphasized once again that the macro-strategic management of colleges and universities is the highest level. Management, the core management, is also the most important management of efficiency impact factors, which determines the validity of other management quality. The following focuses on the management of local universities in Shaanxi from the perspective of macro management. University management is also an important source of soft power within universities. This soft power has more hidden and unknown features than thought and cultural power. When bad management is flooding the running of colleges and universities, we will ruthlessly accuse the existence of "extra" or even "detestable" dependence on college teachers and students, but when management reflects higher wisdom and even forms a similar In the inertia of culture, and making colleges and universities clear-cut, clear-cut, 
well-organized, full of vitality and vitality, we do not seem to realize the existence of management. Therefore, the management of colleges and universities must be based on scientific management, democratic management, efficient management, and humanized management.

\section{Conclusion}

This paper analyzes the status quo, problems and subjective and objective constraints of soft power construction in local colleges and universities in Shaanxi. The conclusion is that the status quo of soft power construction in local colleges and universities in Shaanxi is in the initial stage, the development of different universities is unbalanced, the essential understanding needs to be improved, and the specific understanding needs to be standardized. The construction of soft power in local colleges and universities in Shaanxi has four major problems: neglecting ideological development, cultural power construction, management capacity building and influence construction. The national education investment policy, the imbalance of education investment in various regions, the policy pattern of internal resource allocation in higher education, the background of higher education development, economic society and its ideological trends, and internal conditions are the six objective constraints of the construction of soft power in colleges and universities. Deep cultural psychology, subjective vacancies in the spirit of education and the persistence of university character, subjective vacancies in thinking about the laws of scientific development and macro development, lack of awareness of the characteristics of soft power construction in local colleges and universities in Shaanxi Subjective constraints in four areas.

\section{Acknowledgements}

Fund Project: Fund Project: 2017 Shaanxi Higher Education Society Project: Research on Shaanxi University Cultural Soft Power Promotion Strategy under the Background of "Belt and Road” (XGH17188)

\section{References}

[1] Li Huashu. On the Soft Power of Universities [J]. Fudan Education Forum, 2005- 03(4)

[2] Tian Jianguo. University Culture and Ideological and Moral Construction [J]. China Higher Education, 2004(22)

[3] Wang Yusheng. University Spirit and System Innovation [J]. Nonferrous Metals Education Research, 2001(1)

[4] Jing Min. Evaluation and Countermeasures [J]. Northeast Asia Forum, 2003- 03 (2)

[5] Ma Zhiqiang. On the Position and Function of Soft Power in Urban Development [J]. Business Economics and Management, 2001-04 (4) 